\title{
Chemical Composition as a Factor Affecting the Mechanical Properties of Thermally Modified Black Poplar (Populus nigra L.)
}

Paweł Kozakiewicz, Michał Drożdżek, * Agnieszka Laskowska, Marek Grześkiewicz, Olga Bytner, Andrzej Radomski, Agnieszka Mróz, Izabela Betlej, and Janusz Zawadzki

\begin{abstract}
Black poplar (Populus nigra L.) was thermally modified in superheated steam at $160^{\circ} \mathrm{C}, 190^{\circ} \mathrm{C}$, and $220^{\circ} \mathrm{C}$ for $2 \mathrm{~h}$. The research identified correlations between the chemical composition and selected mechanical properties of thermally modified wood. The higher treatment temperatures significantly lowered the modulus of rupture (MOR) and the Brinell hardness $(\mathrm{BH})$. These correlations were particularly apparent at higher temperatures $\left(190{ }^{\circ} \mathrm{C}\right.$ and $\left.220{ }^{\circ} \mathrm{C}\right)$ when thermally modified wood experienced stronger hemicelluloses degradation, which was indicated by an increase in the content of non-structural substances. The wood properties including compressive strength parallel to the grain (CS), modulus of elasticity during bending (MOE), and compressing (MCS) were affected less by the chemical changes caused by the thermal processing of wood. Moreover, the level of wood moisture content also affected these changes.
\end{abstract}

Keywords: Chemical composition; Compressive strength; Hardness; Modulus of rupture; Poplar; Thermal modification

Contact information: Faculty of Wood Technology, Warsaw University of Life Sciences - SGGW, 159

Nowoursynowska St., 02-776 Warsaw, Poland; *Corresponding author: michal_drozdzek@sggw.pl

\section{INTRODUCTION}

Poplars and some willow species are some of the fastest growing trees in the temperate climate zone. The ubiquity of poplar wood results from its low environmental requirements and extremely fast growth. In Poland, there are three common poplar species: aspen (Populus tremula L.), silver poplar (Populus alba L.), and black poplar (Populus nigra L.) (Mirek et al. 2002). Black poplar plays an important role in the wood industry and the advantage of this species consists in its plantation potential resulting from a fast increase of biomass (Niemczyk et al. 2016). This has been confirmed by the inclusion of black poplar in the EN 13556 (2003) standard concerning wood terminology in the European trade, where it has the 4-letter code PONG.

Black poplar wood has low density, resulting in low resistance parameters and low natural durability. Moreover, black poplar is highly hygroscopic and undergoes important dimensional variations, which limits its applications (Galewski and Korzeniowski 1958; Wagenführ 2007). These characteristics are even less favorable in fast-growing plantation trees (Hernández et al. 1998; Goyal et al. 1999; Cisneros et al. 1996; Balatinecz et al. 2001; Klasnja et al. 2003). Juvenile wood and sapwood dominate in the trunks of those trees.

One way to improve wood properties is thermal modification. The temperature of the modification process plays a crucial role for the final effect and should be adjusted for the species of wood. Usually, thermal modification of wood is carried out between 160 and 
$230{ }^{\circ} \mathrm{C}$ (Majano-Majano et al. 2012; Oliver-Villanueva et al. 2013; Shchupakivskyy et al. 2014; Zauer et al. 2014; Sandak et al. 2015; Candelier et al. 2017).

At the beginning, the increase of temperature during wood modification causes a reduction of its mass due to loss of water and release of volatile organic compounds. Further increases in wood modification temperature causes a loss of mass due to changes in the structure of the polymer components of cell walls, which are mostly carbohydrate ingredients and lignin. The degree of mass loss depends on the wood species, temperature, time of the modification process, sample dimensions, as well as the modification atmosphere applied, e.g., water vapor or nitrogen (Hill 2006; Gawron 2012).

Deciduous species are more susceptible to high temperatures than coniferous species (Hill 2006). The thermal process and its final effects depend to a large extent on the chemical composition of a given wood species, including the type and content of nonstructural compounds, which govern the $\mathrm{pH}$ and other aspects. Poplar wood is slightly acidic up to neutral ( $\mathrm{pH}$ from 5.8 to 6.7). It does not contain many non-structural substances. Compounds soluble in hot water amount to only $1.4 \%$ to $2.7 \%$ of poplar wood mass (Galewski and Korzeniowski 1958; Wagenführ 2007).

Thermal modification lowers the hygroscopicity of wood structures, causing the wood to absorb less moisture (Akyildiz and Ateş 2008; Brito et al. 2018). The improvement of this property results from changes in the chemical composition of wood, mostly because of hemicelluloses degradation caused by high temperatures (Boonstra et al. 1998; Lovrić et al. 2014). The changes in the properties of thermally modified wood depend on the conditions of the modification process (Kocaefe et al. 2008; Candelier et al. 2013; Hannouz et al. 2015). When deciding the parameters of thermal modification, it is important to consider the initial values of individual properties of the wood.

The changes in wood moisture content in the hygroscopic range and its temperatures have an important influence on the elastic properties of wood, including its compressive strength parallel to the grain and the type of structural damage (Kozakiewicz 2010). During compression, cell walls undergo an abrupt deformation, which leads to destruction at lower load values than in the case of tensile tests (Kollmann 1951). Poulsen et al. (1997) mentions that wood destruction begins in areas of misaligned tracheids located directly next to pith rays, which corresponds to Tiemann's drawings (1944). In the final stage, cell walls bend and become separated, usually between the secondary wall tissue areas of S1 and S2 (Dinwoodie 1981). An important factor affecting the process of wood compression is the inclination of fibrils in cell walls and their position in the S2 tissue area of the secondary wall is decisive. Initiation of microscopic damages can happen already at loads equivalent to 25\% of the failure load (Grossman and Wold 1971; Poulsen et al. 1997).

There are many publications on the influence of the intensity of the thermal process conditions on the chemical and physical properties of wood (Rowell et al. 2002; Yildiz and Gümüşkaya 2005). Nonetheless, the mechanical properties of wood species with plantation potential after the thermal process remain unclear. This research can elucidate the use of thermally processed wood for elevations or interior panelling and battens. The main purpose of the study was to determine the relations between conditions of the thermal process and the chemical composition and mechanical properties of black poplar (Populus nigra L.) wood. The mechanical properties of thermally modified black poplar wood were analyzed at different moisture content levels. 


\section{EXPERIMENTAL}

\section{Materials}

Black poplar (Populus nigra L.) sapwood was obtained from a plantation forest in Poland (the eastern part of the Mazovian province, State Forest District Sokołów Podlaski). The solid wood of 40-year-old poplars was used. The trees had a diameter at breast height $(\mathrm{DBH})$ up to $0.5 \mathrm{~m}$ and a mean growth ring width greater than $5 \mathrm{~mm}$. The round wood was sawn into boards in a sawmill located in this region. Wood was supplied in the form of selected air-dried timber that was $21 \mathrm{~mm}$ thick (radial), $140 \mathrm{~mm}$ wide (tangential), and $2500 \mathrm{~mm}$ long (longitudinal). High quality timber was used without material defects such as knots, tangled fibers, cracks, insect trails, or rot. The timber was cut into several groups with the same number of samples, therefore creating twin sets of samples with similar average density. The dimensions of the samples used for thermal modification were as follows: $300 \mathrm{~mm}$ (longitudinal), $20 \mathrm{~mm}$ (tangential), and $20 \mathrm{~mm}$ (radial). The surface of the wood samples was finished by planing. One set of samples was treated as a control group and was not subjected to thermal modification. The control samples as well as samples after different variants of thermal modification were divided into smaller samples for the purpose of testing individual properties.

\section{Methods}

\section{Thermal modification}

Black poplar was modified in superheated steam under laboratory conditions. Modification temperatures were $160{ }^{\circ} \mathrm{C}, 190{ }^{\circ} \mathrm{C}$, and $220{ }^{\circ} \mathrm{C}$ over a period of $2 \mathrm{~h}$. The process of modification had several phases: drying, gradual increase of temperature, thermal heating, and cooling. The first phase of thermal modification involved the intense (fast) heating of wood to $110^{\circ} \mathrm{C}$ and air drying for $12 \mathrm{~h}$. The next phase involved the slow heating $\left(10^{\circ} \mathrm{C}\right.$ every hour) of wood up to the temperature $130{ }^{\circ} \mathrm{C}$ and air drying for $2 \mathrm{~h}$. The next phase involved the slow heating of wood up to the temperature of the thermal modification process itself $\left(160{ }^{\circ} \mathrm{C}, 190{ }^{\circ} \mathrm{C}\right.$, or $\left.220^{\circ} \mathrm{C}\right)$ in the atmosphere of superheated steam. Next, the wood was carried out at a constant temperature of either $160{ }^{\circ} \mathrm{C}, 190{ }^{\circ} \mathrm{C}$, or $220^{\circ} \mathrm{C}$ in the atmosphere of superheated steam and lasted for $2 \mathrm{~h}$. Lastly, the wood was cooled for $12 \mathrm{~h}$ by turning off the heating and unsealing the chamber.

\section{Air conditioning and determination of basic physical properties}

Wood samples with the dimensions of $300 \mathrm{~mm}$ (longitudinal), $20 \mathrm{~mm}$ (tangential), and $20 \mathrm{~mm}$ (radial) were placed in containers in which the relative humidity was $76 \% \pm$ $2 \%$ at a temperature of $20{ }^{\circ} \mathrm{C} \pm 2{ }^{\circ} \mathrm{C}$. These are conditions in which non-modified wood reaches equilibrium moisture content (EMC) of $c a .12 \%$, as required by the standards for the tests of mechanical properties. Wood conditioning under the test conditions was achieved using a saturated solution of sodium chloride. The chemical used was of proanalysis (p.a.) grade and was obtained from Chempur (Piekary Śląskie, Poland). The wood EMC was measured when the mass of the wood samples remained unchanged over three measurements of weight at $48 \mathrm{~h}$ intervals. The mass of the samples was determined with an accuracy of $\pm 0.001 \mathrm{~g}$. The relative humidity was measured using an AZ 9871 anemometer (AZ Instrument Corp., Taichung City, Taiwan). Twelve samples were used for testing sorption (adsorption) properties. The density of wood was determined in accordance to the ISO 13061-2 (2014) standard and moisture content according to ISO 13061-1 (2014). 


\section{Chemical composition}

Wood that had been ground in a laboratory mill was used for chemical analyses. Subsequently, the ground wood was sieved in order to obtain the flour fraction between 0.43 and $1.02 \mathrm{~mm}$. Three samples were used for each of the tests. Approximately $5 \mathrm{~g}$ of wood meal flour was extracted for $10 \mathrm{~h}$ using a Soxhlet extractor, with a chloroformethanol solvent mixture (ratio of 93 to 7 volume per volume) (Antczak et al. 2006). The lignin, cellulose, and holocellulose contents were determined for the solvent-extracted wood meal. The cellulose content was determined using the well-known Kürschner-Hoffer method (1929). The holocellulose content was determined by a means of acid chlorite delignification of the extracted wood meal using sodium chlorite in an acid medium as described by Wise et al. (1946). The content of hemicelluloses in poplar wood was calculated based on the difference in the content of holocellulose and cellulose. The amount of acid-insoluble lignin was determined in accordance to TAPPI T $222 \mathrm{om}-15$ (2015), and the amount of acid-soluble lignin was determined in accordance with the NREL/TP-51042618 lab procedure (Sluiter et al. 2011) using a UV/Vis wavelength of $205 \mathrm{~nm}$. The content of lignin was the amount of insoluble and soluble lignin (Table 2).

The tests were conducted using analytical grades of sulfuric acid solution $95 \%$ pure p.a, nitric acid $65 \%$ pure, and chloroform that was obtained from Chempur (Piekary Śląskie, Poland). The sodium chlorite that was used was of reagent grade and was purchased from Sigma-Aldrich (Poznań, Poland). The ethanol that was used was of technical grade, which was procured from Linegal Chemicals (Warsaw, Poland).

\section{Determination of the mechanical properties of black poplar}

The modulus of rupture (MOR) and modulus of elasticity (MOE) tests of black poplar were carried out in accordance with the methodology specified in the ISO 13061-3 (2014) and ISO 13061-4 (2014) standards. The MOR and MOE analysis was carried out using a computer program coupled with the Instron $^{\circledR}$ testing machine, model 3369 (Norwood, MA, USA).

The tests of compressive strength parallel to the grain (CS) of black poplar were carried out in accordance with ISO 13061-17 (2017), and the samples used for these tests had a cuboid shape with cross section dimensions of 20 by $20 \mathrm{~mm}$ and a length of $60 \mathrm{~mm}$. The tests of compressive strength parallel to the grain were carried out using a computer program coupled with the Instron ${ }^{\circledR}$ testing machine, model 3382. By using the LVDT displacement sensor, it was possible to automatically calculate the compressive modulus. The appearance of samples after this test was analyzed according to the ASTM D 143-94 (2000) standard.

The wood hardness was examined using the Brinell method in accordance with the requirements of EN 1534 (2010). The Brinell hardness was determined on the tangential surface of the sample. Hardness measurements were conducted using the universal testing machine CV-3000LDB manufactured by C.V. Instruments Ltd. (Sheffield, UK). The machine was equipped with a $10 \mathrm{~mm}$ diameter indenter, and the dwell time was equal to 15 seconds. The maximum load was $1 \mathrm{kN}$.

All the mechanical properties were determined for 12 samples of each variant of thermal modification of black poplar and two variants of moisture content: $0 \%$ and EMC (in the air relative humidity of $76 \% \pm 2 \%$ and air temperature of $20{ }^{\circ} \mathrm{C} \pm 2{ }^{\circ} \mathrm{C}$ ). 


\section{Statistical analysis}

Statistical analyses were performed using STATISTICA version-12 software from StatSoft, Inc. (Tulsa, OK, USA). The statistical analysis of the results was carried out using a significance level (p) of 0.050 . The significance of differences between the control group (non-modified black poplar) and individual variants of thermally modified black poplar based on a t-test, was determined (s-statistically significant differences $\mathrm{p}<0.050$, nsstatistically insignificant differences $\mathrm{p}>0.050$ ).

\section{RESULTS AND DISCUSSION}

The density of black poplar wood at the moisture content of $12 \%$ amounts on average to $450 \mathrm{~kg} / \mathrm{m}^{3}$ and changes in the typical range of $410 \mathrm{~kg} / \mathrm{m}^{3}$ to $560 \mathrm{~kg} / \mathrm{m}^{3}$ (Galewski and Korzeniowski 1958; Wagenführ 2007). The average density of nonmodified black poplar wood (exposed to $76 \% \pm 2 \%$ relative humidity at the temperature of $20{ }^{\circ} \mathrm{C} \pm 2{ }^{\circ} \mathrm{C}$ amounted to $384 \pm 21 \mathrm{~kg} / \mathrm{m}^{3}$ (Table 1 ). This density is clearly lower than the value in the reference tables. This can be explained by the young age of the analyzed wood, which is dominated by juvenile wood in the studied material. The logging of young trees is typical for plantations of fast-growing species (Niemczyk et al. 2016), and the data for this type of wood has not been included in the atlas reference tables so far (Galewski and Korzeniowski 1958; Wagenführ 2007). However, they can be found in publications. For example, the average density in the absolute dry state of the poplar hybrids grown in North America falls within the range between $300 \mathrm{~kg} / \mathrm{m}^{3}$ to $390 \mathrm{~kg} / \mathrm{m}^{3}$ (Balatinecz et al. 2001). This corresponds to documented values of poplar wood density published by other researchers (Goyal et al. 1999; Klasnja et al. 2003).

The process of thermal modification causes an important reduction in poplar wood density, which is more significant in higher temperatures. The observed reduction of average density results partially from a mass loss of thermally modified samples and partially from changes in hygroscopic properties. The reduction could be due to the lower equilibrium moisture content for the given constant climate parameters (Table 1).

Table 1. Density and Equilibrium Moisture Content (EMC) of Thermally Modified Black Poplar Sapwood Exposed to $76 \% \pm 2 \%$ Relative Humidity at $20^{\circ} \mathrm{C} \pm 2{ }^{\circ} \mathrm{C}$

\begin{tabular}{|c|c|c|}
\hline Modification Temperature $\left({ }^{\circ} \mathrm{C}\right)$ & Density $\left(\mathrm{kg} / \mathrm{m}^{3}\right)$ & EMC $(\%)$ \\
\hline non-modified & $384(21)$ & $10.63(0.32)$ \\
\hline 160 & $388(20)$ & $10.54(0.21)$ \\
\hline 190 & $372(15)$ & $8.57(0.22)$ \\
\hline 220 & $336(10)$ & $6.24(0.06)$ \\
\hline
\end{tabular}

The process of thermal modification causes changes in the percentual content of structural and non-structural compounds in black poplar wood (Table 2). Native poplar wood is characterized by a low content of non-structural compounds soluble in $1 \% \mathrm{NaOH}$, which is indirectly in line with information from wood atlases concerning the content of non-structural compounds soluble in hot water (Galewski and Korzeniowski 1958; Wagenführ 2007). However, a high carbohydrate content was observed. Native black poplar wood contains about $80 \%$ of holocellulose, and $52 \%$ of cellulose. Hemicelluloses content, calculated from the difference between the content of holocellulose and cellulose, amounts to ca. $30 \%$. Lignin content in native wood is approximately $25 \%$. The composition 
of black poplar wood described above is in line with the reference literature data (Prosiński 1984). During thermal modification, hemicelluloses undergoes the most significant changes in their percentual share in wood composition (Sivonen et al. 2002). Poplar wood contains homogeneous hemicelluloses (mostly xylan) and mixed hemicelluloses. The carboxyl and acetyl groups in the mixed hemicelluloses have a significant impact on the thermal stability of hemicelluloses. The formic and acetic acids created mostly from $\mathrm{O}$ acetyl-galactoglucomannan as a result of the modification temperature accelerate and additionally catalyze the hydrolysis and decomposition of hemicelluloses (Kollmann and Fengel 1965; Gawron 2012).

Table 2. Chemical Composition of Thermally Modified Black Poplar (Standard Deviation in Parentheses)

\begin{tabular}{|c|c|c|c|c|c|}
\hline $\begin{array}{c}\text { Modification } \\
\text { Temperature } \\
\left({ }^{\circ} \mathrm{C}\right)\end{array}$ & Cellulose (\%) & $\begin{array}{c}\text { Holocellulose } \\
(\%)\end{array}$ & $\begin{array}{c}\text { Hemicelluloses } \\
(\%)\end{array}$ & Lignin (\%) & $\begin{array}{c}\text { Extractives } \\
(\%)\end{array}$ \\
\hline non-modified & $52.15(0.49)$ & $82.11(0.34)$ & $29.96(0.83)$ & $24.12(0.48)$ & $1.80(0.03)$ \\
\hline 160 & $53.20(0.35)^{\mathrm{s}}$ & $81.72(0.33)^{\mathrm{ns}}$ & $28.52(0.68)^{\mathrm{s}}$ & $23.45(0.83)^{\mathrm{ns}}$ & $2.40(0.05)^{\mathrm{s}}$ \\
\hline 190 & $54.42(0.44)^{\mathrm{s}}$ & $75.07(0.20)^{\mathrm{s}}$ & $20.65(0.63)^{\mathrm{s}}$ & $22.41(1.08)^{\mathrm{ns}}$ & $3.90(0.17)^{\mathrm{s}}$ \\
\hline 220 & $60.12(0.45)^{\mathrm{s}}$ & $63.70(0.25)^{\mathrm{s}}$ & $3.58(0.71)^{\mathrm{s}}$ & $30.760 .21)^{\mathrm{s}}$ & $6.40(0.06)^{\mathrm{s}}$ \\
\hline
\end{tabular}

The $33 \%$ increase in the content of extractives and the 5\% decrease of hemicelluloses in the black poplar wood after thermal modification at $160{ }^{\circ} \mathrm{C}$ were observed (statistically significant differences, based on t-test, $p<0.050$ ). At $190{ }^{\circ} \mathrm{C}$, perceptible increases of cellulose content in wood and most non-structural compounds were due to the acetyl and carboxyl groups which form carbon acids and hydrolysis wood material (Nishimura et al. 1983; Fengel and Wegener 2003; Gosselink et al. 2004). The increase was also due to the hemicelluloses degradation into volatile and liquid products of decomposition as products of hemicelluloses decomposition (Boonstra et al. 2007; Gérardin et al. 2007). Lignin content slightly decreased as a result of changes in the lignin structure in its guaiacyl and syringyl forms. In these temperatures, the aryl-ether linkages between lignin's phenylpropane units tend to break (Erçin and Yürüm 2003; Pandey and Pitman 2003; Wikberg and Maunu 2004).

At the modification temperature of $220^{\circ} \mathrm{C}$, changes in the chemical composition of thermally modified wood were the most significant. Hemicelluloses were almost entirely decomposed into volatile and liquid products of decomposition. At the same time, there was an apparent increase in the cellulose and lignin content in the modified wood and the highest content of substances that are not bound structurally within wood structure. In modification temperatures of $200{ }^{\circ} \mathrm{C}$, the structure of lignin molecules becomes more condensed (Funaoka et al. 1990).

The changes in carbohydrate content observed at high modification temperatures are due to the degradation of hemicelluloses and cellulose chains with a low degree of polymerization, which is mostly amorphic cellulose (Wikberg and Maunu 2004). For example, when Scots pine is thermally modified in superheated steam at the temperature of $200{ }^{\circ} \mathrm{C}$, important changes were already observed in the molar mass of cellulose as well as its depolymerization (Zawadzki et al. 2016). The probable decomposition of a part of the amorphous cellulose leads to the creation of cyclic furan compounds among others, 
hydroxymethylfurfural. Due to a high thermal resistance of cellulose, these changes happen only to a limited extent. Moreover, an increase in cellulose crystallinity can be observed (Fengel and Wegener 2003; Yildiz and Gümüşkaya 2005; Zawadzki 2009; Gawron 2012).

The non-modified black poplar wood tested in an absolute dry state (control samples) had a compressive strength parallel to the grain (CS) of $48.2 \mathrm{MPa} \pm 3.6 \mathrm{MPa}$ and at EMC 29.1 MPa $\pm 2.8 \mathrm{MPa}$ (Fig. 1a). The achieved CS values were proportional to the low density of wood under research. At the same time, these values were lower than the characteristic value for mature black poplar wood. The typical range of CS given in reference literature for black poplar wood with $12 \%$ moisture content is between $48 \mathrm{MPa}$ and $70 \mathrm{MPa}$ (Galewski and Korzeniowski 1958; Wagenführ 2007). According to Hernández et al. (1998), the CS of juvenile poplar wood is much lower than the strength parameter obtained for mature wood. This has been confirmed by Cisneros et al. (1996), who concluded that juvenile poplar wood has a significantly lower strength in comparison with mature wood, due to a bigger angle of cellulose microfibrils inclination and shorter fibers.

a)

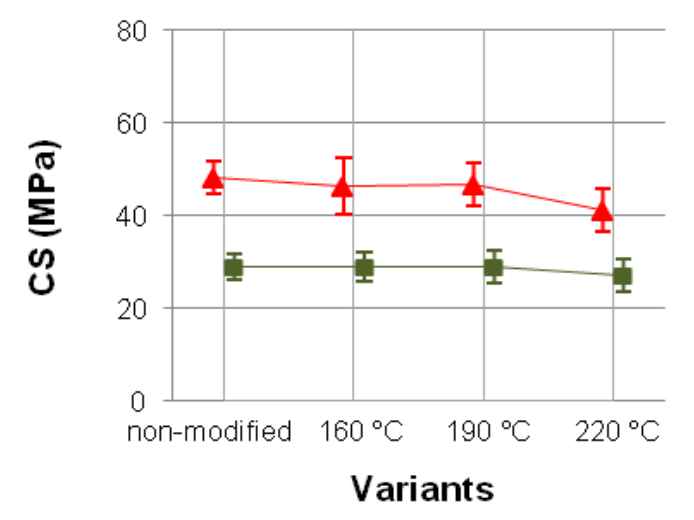

b)

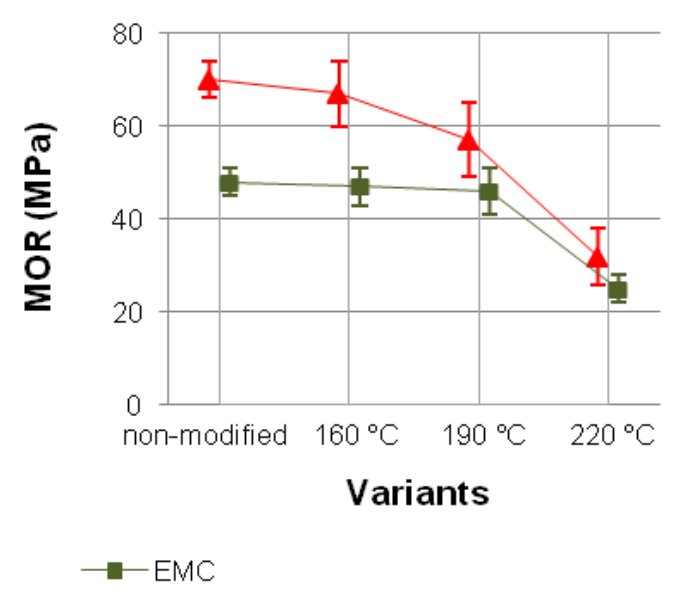

Fig. 1. Strength of thermally modified black poplar wood: (a) compressive strength parallel to the grain - CS and (b) bending strength (modulus of rupture) - MOR (error bars - standard deviation)

The CS of black poplar wood modified at the temperature of $220^{\circ} \mathrm{C}$ in the absolute dry state amounted to $41.2 \mathrm{MPa} \pm 4.6 \mathrm{MPa}$ and at an EMC of 27.1 MPa $\pm 3.4 \mathrm{MPa}$ (Fig. 1a). In comparison with the CS of non-modified black poplar wood, these values were lower by $15 \%$ and $7 \%$, respectively (statistically significant differences, t-test, $p<0.050$ ). On the other hand, the CS of wet black poplar wood, independently from the temperatures of thermal modification, amounted to $60 \%$ of the CS determined for the absolute dry poplar wood.

It can be concluded that the thermal process and the resulting changes in black poplar wood chemical composition did not affect CS as much as the moisture content (MC) of the material did. This was confirmed by statistical analysis (Table 3 ). The temperature of treatment had a significant impact on the CS of black poplar wood only at the level of $3 \%$, while moisture content significantly affected the CS of black poplar with an impact of $85 \%$ (based on the sum of squares). 
Table 3. Statistical Evaluation of the Factors Influencing the Properties of Thermally Modified Black Poplar

\begin{tabular}{|c|c|c|c|c|c|}
\hline \multirow[t]{2}{*}{ Property } & \multirow[t]{2}{*}{ Factor } & $\begin{array}{c}\text { Sum } \\
\text { of } \\
\text { Squares }\end{array}$ & $\begin{array}{c}\text { Fisher's } \\
\text { F-test }\end{array}$ & $\begin{array}{c}\text { Significance } \\
\text { Level }\end{array}$ & \multirow[t]{2}{*}{$\begin{array}{c}\text { Factor } \\
\text { Influence } \\
(\%)\end{array}$} \\
\hline & & SS & $\mathrm{F}$ & $p$ & \\
\hline \multirow[t]{5}{*}{ CS } & Intercept & 65794.91 & 5913.171 & 0.000000 & - \\
\hline & Temp. (1) & 140.75 & 4.216 & 0.011076 & 3 \\
\hline & $\mathrm{MC}(2)$ & 3547.67 & 318.839 & 0.000000 & 85 \\
\hline & $1 \times 2$ & 42.88 & 1.284 & 0.292838 & 1 \\
\hline & Error & 445.07 & - & - & 11 \\
\hline \multirow[t]{5}{*}{ MOR } & Intercept & 57624.00 & 1752.821 & 0.000000 & - \\
\hline & 1 & 3411.67 & 34.592 & 0.000000 & 61 \\
\hline & 2 & 1380.17 & 41.982 & 0.000008 & 25 \\
\hline & $1 \times 2$ & 232.17 & 2.354 & 0.110532 & 5 \\
\hline & Error & 526.00 & - & - & 9 \\
\hline \multirow[t]{5}{*}{ MCS } & Intercept & 1306.514 & 2582.248 & 0.000000 & - \\
\hline & 1 & 2.507 & 1.652 & 0.192751 & 5 \\
\hline & 2 & 25.202 & 49.811 & 0.000000 & 51 \\
\hline & $1 \times 2$ & 1.901 & 1.252 & 0.303751 & 4 \\
\hline & Error & 20.238 & - & - & 40 \\
\hline \multirow[t]{5}{*}{ MOE } & Intercept & 667393067 & 1609.142 & 0.000000 & - \\
\hline & 1 & 1097241 & 0.882 & 0.471347 & 11 \\
\hline & 2 & 2330020 & 5.618 & 0.030683 & 23 \\
\hline & $1 \times 2$ & 3130 & 0.003 & 0.999818 & 0 \\
\hline & Error & 6636016 & - & - & 66 \\
\hline \multirow[t]{5}{*}{$\mathrm{BH}$} & Intercept & 1947.831 & 3580.431 & 0.000000 & - \\
\hline & 1 & 13.065 & 24.016 & 0.000160 & 29 \\
\hline & 2 & 19.614 & 12.018 & 0.000227 & 43 \\
\hline & $1 \times 2$ & 4.033 & 2.471 & 0.099148 & 9 \\
\hline & Error & 8.704 & - & - & 19 \\
\hline
\end{tabular}

The modulus of rupture (MOR) of non-modified black poplar in the absolute dry state amounted to $70.0 \mathrm{MPa} \pm 4.0 \mathrm{MPa}$, and the EMC amounted to $48.0 \mathrm{MPa} \pm 3.0 \mathrm{MPa}$. The values of bending strength of black poplar samples without any defects fell in the wide range of values given in the reference literature, which is from 40 to $94 \mathrm{MPa}$ (Galewski and Korzeniowski 1958; Wagenführ 2007). In the case of MOR, the negative impact of thermal modification temperature was particularly visible (Fig. 1b), especially for the absolute dry wood. The higher the temperature of the modification process, the lower was the MOR value of black poplar wood tested in the absolute dry state. However, the MOR of black poplar in a state of hygroscopic balance (exposed to $76 \% \pm 2 \%$ relative humidity at the temperature of $20{ }^{\circ} \mathrm{C} \pm 2{ }^{\circ} \mathrm{C}$ ) changed significantly after modification in $220{ }^{\circ} \mathrm{C}$ (a reduction by $48 \%$ ). In the case of wet wood, the reduction of MOR was partially "masked" by the material becoming more hydrophobic and assuming lower equilibrium moisture values for thermally modified wood (the higher the temperature of the modification process, the lower the equilibrium moisture), which has been presented in Table 1. The statistical analysis (ANOVA, Fischer's F-test) showed that MOR was dependent (i.e. factor influence determined on the sum of squares) to a $61 \%$ degree on the modification temperature and to a $25 \%$ degree on the wood moisture content (Table 3 ). 
a)

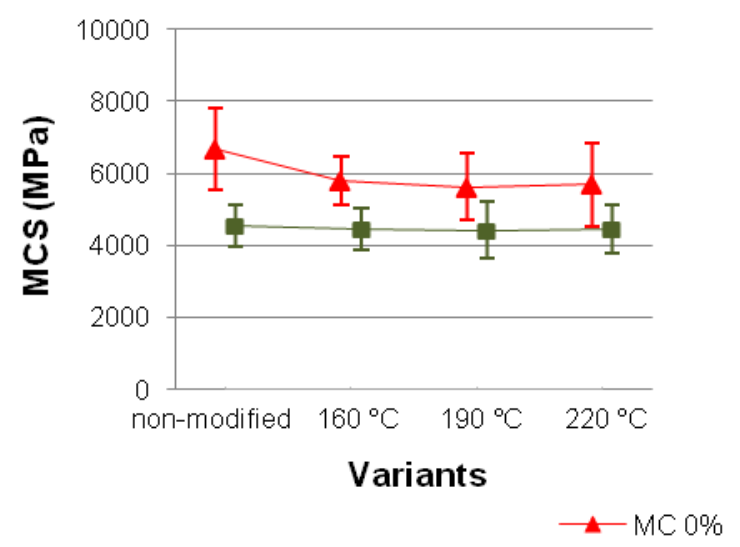

b)

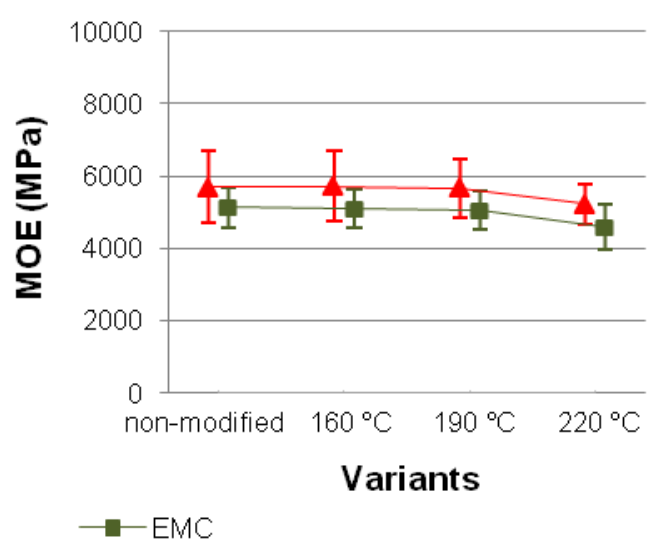

Fig. 2. (a) Compressive modulus - MCS and (b) modulus of elasticity - MOE of thermally modified black poplar wood (error bars - standard deviation)

Figure 2 presents the results of the modulus of elasticity with compression parallel to the grain (MCS) and with static bending strength (MOE). The values of both moduli were similar, just like the character of their changes. It was shown that the modification temperature did not significantly influence the differences in MCS and MOE values. The value of the moduli depended on the wood moisture content (Table 3). The values of these moduli determined for black poplar wood in the absolute dry state fell in the range from of ca. $5200 \mathrm{MPa}$ to $6700 \mathrm{MPa}$ and in wet wood from $c a$. $4400 \mathrm{MPa}$ to $5000 \mathrm{MPa}$. These are typical values for juvenile wood, which are significantly lower than the moduli of elasticity of mature wood (Galewski and Korzeniowski 1958; Wagenführ 2007). The higher the temperature of modification, the lower the EMC values of black poplar wood, as shown in the Table 1. As a result, this determines the phenomenon of a small variation in the value of moduli depending on the temperature of the modification process with simultaneous changes in the chemical composition of wood. Regardless of the modification temperature, the MCS values for black poplar wood in wet state (EMC) constituted approx. $80 \%$ of the MCS values in the dry state. In the case of MOE, this ratio was about $90 \%$.

a)

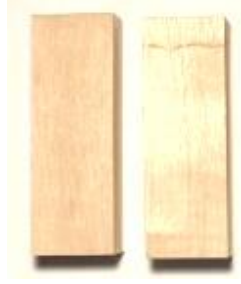

c)

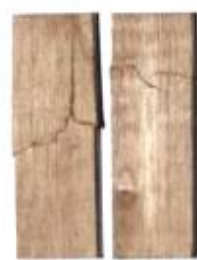

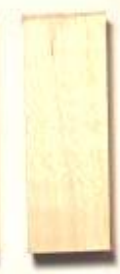
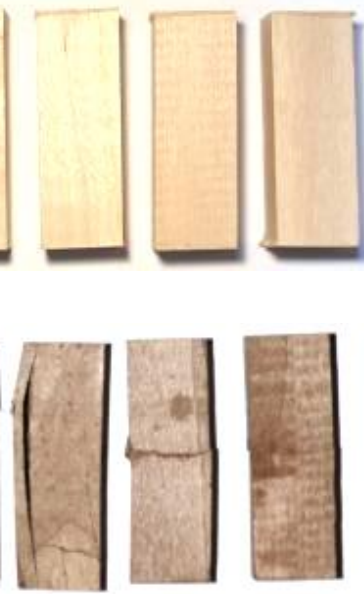

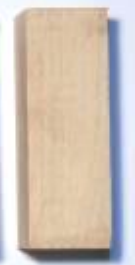

b)
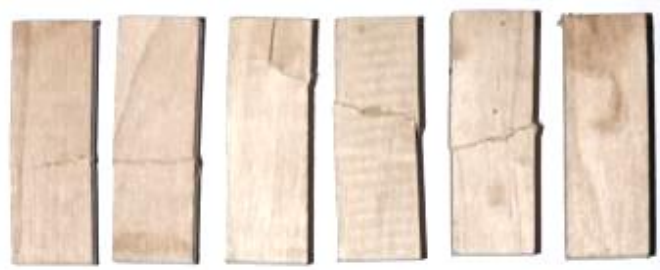

d)
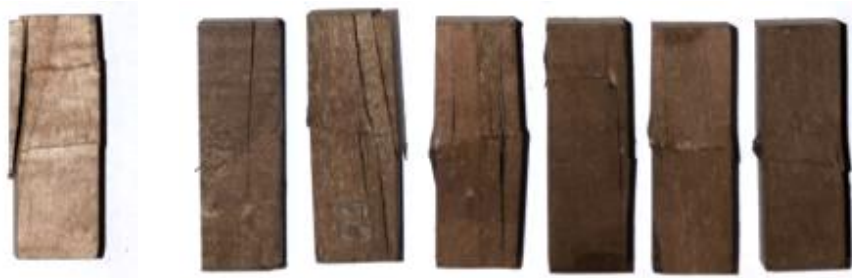

Fig. 3. The typical appearance of the samples after the compressive test depending on the modification temperature: a) non-modified, b) $160^{\circ} \mathrm{C}$, c) $190^{\circ} \mathrm{C}$ d) $220^{\circ} \mathrm{C}$ 
The changes in the elastic properties of thermally modified black poplar wood in comparison with control samples can be confirmed by the appearance of typical damage caused to the samples by the compressive test parallel to the grain (Fig. 3). Control samples in the absolute dry state were damaged as a result of brooming or end-rolling of fibers on the front surface of the samples. This is the typical damage appearance for low density wood with a homogeneous structure and a straight fiber layout (Kozakiewicz 2010). Higher temperatures of the modification process caused the material to become more brittle (plasticity reduction). The dominating type of damage after a thermal process in $160{ }^{\circ} \mathrm{C}$ was crushing and shearing. After modification at the temperature of $190{ }^{\circ} \mathrm{C}$, apart from the above-mentioned types of damage, wedge splits also appeared as well as a few cases of splitting. The wood of black poplar thermally modified in $220^{\circ} \mathrm{C}$ and later subjected to the compressive test suffered mostly from the splitting type of damage, compression, and sparing parallel to the grain, as well as shearing. The changes in black poplar wood elastic properties were related to the increasing degradation of hemicelluloses, which became more intense at higher temperatures of the modification process.

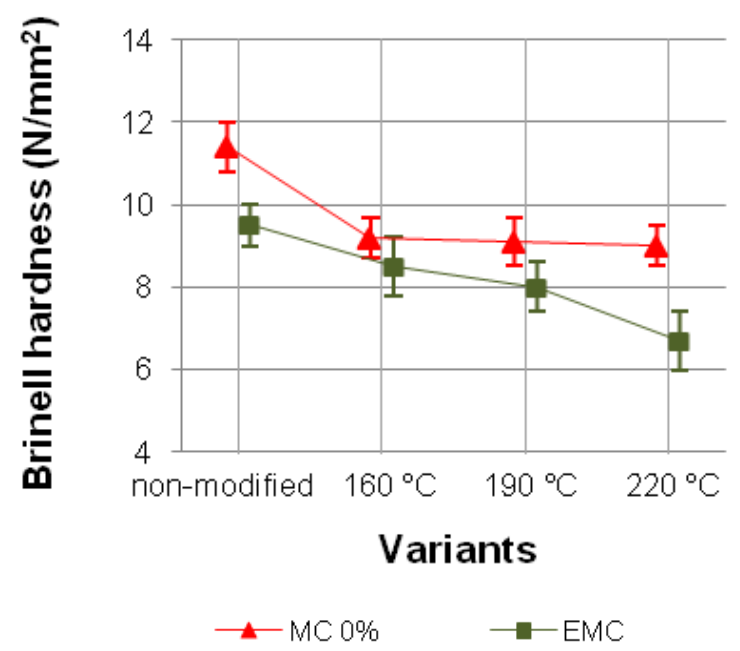

Fig. 4. Brinell hardness of thermally modified black poplar wood (error bars - standard deviation)

Brinell hardness $(\mathrm{BH})$ on the tangential section of non-modified black poplar wood in the absolute dry state amounted to $11.4 \mathrm{~N}$ per $\mathrm{mm}^{2} \pm 0.6 \mathrm{~N}$ per $\mathrm{mm}^{2}$ and in the wet state (at the equilibrium moisture reached by wood exposed to $76 \% \pm 2 \%$ relative humidity at the temperature of $\left.20{ }^{\circ} \mathrm{C} \pm 2{ }^{\circ} \mathrm{C}\right) 9.5 \mathrm{~N}$ per $\mathrm{mm}^{2} \pm 0.5 \mathrm{~N}$ per $\mathrm{mm}^{2}$. These values were significantly lower than those given in the tree atlases for mature wood (Galewski and Korzeniowski 1958; Wagenführ 2007). The low density of the wood under research played a crucial role in this case.

Hardness tests make use of an indentation device that applies a load to the surface of wood. Chemical changes are the most intense on the surface of thermally modified wood, due to which can be observed as a very clear impact of this process on hardness results. The crucial factor in the case of hardness tests of wood in the absolute dry state is the fact that it underwent a thermal modification process as such (the temperature of the modification does not matter). In the case of wet wood, the influence of the temperature of the modification is visible (Fig. 4). In general, the BH of black poplar wood in the absolute dry state was at a similar level of $9.0 \mathrm{~N}$ per $\mathrm{mm}^{2}$, independently from the temperature of modification (reduction by $20 \%$ in comparison with the $\mathrm{BH}$ of non-modified black poplar 
wood). On the other hand, in the case of wet wood, the reduction of $\mathrm{BH}$ was more significant in the case of higher temperatures of the thermal modification process. The $\mathrm{BH}$ of poplar wood modified in $220{ }^{\circ} \mathrm{C}$ dropped by approximately $29 \%$.

\section{CONCLUSIONS}

1. Thermal modification in superheated steam caused an important reduction of black poplar wood density, which was more severe at higher temperatures of thermal modification.

2. The temperature of the thermal modification process was the decisive factor determining the chemical composition of black poplar wood. The thermal process mostly caused hemicelluloses degradation, which resulted in an apparent increase of the share of cellulose and non-structural wood components.

3. The higher the temperature of the modification process, the more significant the reduction of static bending strength (modulus of rupture, MOR) and Brinell hardness $(\mathrm{BH})$ in the tangential section. Such wood properties as compressive strength parallel to the grain (CS) and moduli of elasticity (MCS, MOE) were not significantly different in various temperatures of the modification process, which means that they do not depend that much on the changes in wood's chemical composition.

4. The level of moisture content of the wood being tested was an important factor in determining the dynamics and character of changes in wood's mechanical properties observed as a result of the thermal process. The changes were much more pronounced in the case of wood in the absolute dry state, while for EMC wood they were usually "masked" by changes caused by reaching different levels of equilibrium moisture.

\section{ACKNOWLEDGMENTS}

This research was financed as part of the project "Intelligent systems for breeding and cultivation of wheat, maize and poplar for optimized biomass production, biofuels and modified wood" (Agreement No. BIOSTRATEG2/298241/10/NCBR/2016), of the National Centre for Research and Development, Poland.

\section{REFERENCES CITED}

Akyildiz, M. H., and Ateş, S. (2008). "Effect of heat treatment on equilibrium moisture content (EMC) of some wood species in Turkey," Research Journal of Agriculture and Biological Sciences 4(6), 660-665.

Antczak, A., Radomski, A., and Zawadzki, J. (2006). "Benzene substitution in wood analysis," Annals of Warsaw University of Life Sciences - SGGW, Forestry and Wood Technology 58, 15-19.

ASTM D 143-94 (2000). "Standard test methods for small clear specimens of timber," ASTM International, U.S.A.

Balatinecz, J. J., Kretschmann, D. E., and Leclercq, A. (2001). "Achievements in the 
utilization of poplar wood - Guideposts for the future," Forestry Chronicle 77(2), 265629. DOI: $10.5558 / \mathrm{tfc} 77265-2$

Boonstra, M., Militz, H., Pizzi, A., Tekely P., and Tjeerdsma, B. F. (1998).

"Characterization of thermally modified wood: Molecular reasons for wood performance improvement," Holz als Roh- und Werkstoff 56(3), 149-153. DOI: $10.1007 / \mathrm{s} 001070050287$

Boonstra, M. J., Van Acker, J., Tjeerdsma, B. F., and Kegel, E. V. (2007). "Strength properties of thermally modified softwoods and its relation to polymeric structural wood constituents," Annals of Forest Science 64(7), 679-690. DOI: 10.1051/forest:2007048

Brito, A. F., Calonego, F. W., Bond, B. H., and Severo, E. T. D. (2018). "Color changes, EMC and biological resistance of thermally modified yellow poplar," Wood and Fiber Science 50(4), 439-446. DOI: 10.22382/wfs-2018-055

Candelier, K., Dumarçay, S., Pétrissans, A., Gérardin, P., and Pétrissans, M. (2013). "Comparison of mechanical properties of heat-treated beech woods cured under nitrogen or vacuum," Polymer Degradation and Stability 98(9), 1762-1765. DOI: 10.1016/j.polymdegradstab.2013.05.026

Candelier, K., Hannouz, S., Thévenon, M.-F., Guibal, D., Gérardin, P., Pétrissans, M., and Collet, R. (2017). "Resistance of thermally modified ash (Fraxinus excelsior L.) wood under steam pressure against rot fungi, soil-inhabiting micro-organisms and termites," European Journal of Wood and Wood Products 75(2), 249-262. DOI: 10.1007/s00107-016-1126-y

Cisneros, H. A., Belanger, L., Wy, G., Watson, P. A., and Hatton, J. V. (1996). "Wood and fiber properties of hybrid poplars from southern British Columbia," TAPPI, Proceedings, Pulping Conference, Books 1 and 2, pp. 675-685.

Dinwoodie, J. M (1981). Timber: Its Nature and Behavior, Van Nostrand Reinhold Co. Ltd. Publisher, New York, Cincinnati, Toronto, London, Melbourne.

EN 1534 (2010). "Wood flooring. Determination of resistance to indentation. Test method," The European Committee for Standardization (CEN), Brussels, Belgium.

EN 13556 (2003). "Round and sawn timber. Nomenclature of timbers used in Europe," European Committee for Standardization, Brussels, Belgium.

Erçin, D., and Yürüm, Y. (2003). "Carbonization of fir (Abies bornmulleriana) wood in an open pyrolysis system at 50-300 ${ }^{\circ} \mathrm{C}$," Journal of Analytical and Applied Pyrolysis 67(1), 11-22. DOI: 10.1016/S0165-2370(02)00011-6

Fengel, D., and Wegener, G. (2003). Wood - Chemistry, Ultrastructure, Reactions, Verlag Kessel, Remagen-Oberwinter, Germany.

Funaoka, M., Kako, T. and Abe, I. (1990). "Condensation of lignin during heating of wood,” Wood Science Technology 24(3), 277-288. DOI: 10.1007/BF01153560

Galewski, W., and Korzeniowski, A. (1958). Atlas Najważniejszych Gatunków Drewna [Atlas of the Major Species of Wood], PWRiL, Warsaw, Poland.

Gawron, J. (2012). Zmiany wybranych właściwości fizyko-chemicznych drewna jesionu wyniostego (Fraxinus excelsior L.) poddanego modyfikacji termicznej [Changes of Selected Physical and Chemical Properties of Ash Wood (Fraxinus excelsior L.) Subjected to Thermal Modification], Ph.D. Dissertation, Faculty of Wood Technology, WULS, Warsaw, Poland.

Gérardin, P., Petrič, M., Petrissans, M., Lambert, J., and Ehrhrardt, J. J. (2007). "Evolution of wood surface free energy after heat treatment," Polymer Degradation and Stability 92(4), 653-657. DOI: 10.1016/j.polymdegradstab.2007.01.016 
Gosselink, R. J. A., Krosse, A. M. A., van der Putten, J. C., van der Kolk, J. C., de KlerkEngels, B., and van Dam, J. E. G. (2004). "Wood preservation by low-temperature carbonization," Industrial Crops and Products 19(1), 3-12. DOI: 10.1016/S09266690(03)00037-2

Goyal, R. L., Fisher, J. J., Krohn, M. J., Packood, R. E., and Olson, J. R. (1999). "Variability in pulping and fiber characteristic of hybrid poplar tress due to their genetic makeup, environmental factors, and tree age," TAPPI 82(5), 141-147.

Grossman, P. U. A., and Wold, M. B. (1971). "Compression fracture of wood parallel to the grain," Wood Science Technology 5(2), 147-156. DOI: 10.1007/bf01134225

Hannouz, S., Collet, R., Buteaud, J. C., Bléron, L., and Candelier, K. (2015). "Mechanical characterization of heat-treated ash wood in relation with structural timber standards," Pro Ligno 11, 3-10.

Hernández, R. E., Koubaa, A., Beaudoin, M., and Fortin, Y. (1998). "Selected mechanical properties of fast-growing poplar hybrid clones," Wood and Fiber Science 30(2), 138-147.

Hill, C. A. S. (2006). Wood Modification: Chemical, Thermal and Other Processes, John Wiley \& Sons Ltd., Chichester, UK.

ISO 13061-1 (2014). "Physical and mechanical properties of wood - Test methods for small clear wood specimens - Part 1: Determination of moisture content for physical and mechanical tests," International Organization for Standardization, Geneva, Switzerland.

ISO 13061-2 (2014). "Physical and mechanical properties of wood - Test methods for small clear wood specimens - Part 2: Determination of density for physical and mechanical tests," International Organization for Standardization, Geneva, Switzerland.

ISO 13061-3 (2014). "Physical and mechanical properties of wood - Test methods for small clear wood specimens - Part 3: Determination of ultimate strength in static bending," International Organization for Standardization, Geneva, Switzerland.

ISO 13061-4 (2014). "Physical and mechanical properties of wood - Test methods for small clear wood specimens - Part 4: Determination of modulus of elasticity in static bending," International Organization for Standardization, Geneva, Switzerland.

ISO 13061-17 (2017). "Physical and mechanical properties of wood - Test methods for small clear wood specimens - Part 17: Determination of ultimate stress in compression parallel to grain," International Organization for Standardization, Geneva, Switzerland.

Klasnja, B., Kopitovic, S., and Orlovic, S. (2003). "Variability of some wood properties of estern cottonwood (Populus deltoides Bartr.) clones," Wood Science Technology 37 (3-4), 331-337. DOI: 10.1007/s00226-003-0179-3

Kocaefe, D., Poncsak, S., and Bulok, Y. (2008). "Effect of thermal treatment on the chemical composition and mechanical properties of birch and aspen," BioResources 3(2), 517-537.

Kollmann, F. F. P. (1951). Technologie des Holzes und der Holzwerkstoffe, Bd. 2, Springer-Verlag, Berlin.

Kollmann, F., and Fengel, D. (1965). “Änderungen der Chemischen Zusammensetzung von Holz durch Thermische Behandlung," Holz als Roh- und Werkstoff 23, 461-468. DOI: $10.1007 / \mathrm{BF} 02627217$

Kozakiewicz, P. (2010). Wptyw temperatury i wilgotności na wytrzymałość na ściskanie wzdtuż włókien wybranych rodzajów drewna o zróżnicowanej gęstości i budowie 
anatomicznej [Effect of Temperature and Moisture Content on Compression Strength Parallel to the Grain of Selected Species of Wood with Variable Density and Anatomical Structures], Treatises and Monographs series of Publishing WULSSGGW, Warsaw, Poland.

Kürschner, K., and Hoffer, A. (1929). "Ein neues Verfahren zur Bestimmung der Cellulose in Hölzern und Zellstoffen," Tech. Chem. Papier Zellstoff Fabr. 26, 125129.

Lovrić, A., Zdravković, V. and Furtula, M. (2014). "Influence of thermal modification on colour of Poplar (Populus x euramericana) rotary cut veneer," Wood Research 59(2), 661-670.

Majano-Majano, A., Hughes, M., and Fernandez-Cabo, J. L. (2012). "The fracture toughness and properties of thermally modified beech and ash at different moisture contents," Wood Science and Technology 46(1-3), 5-21. DOI: 10.1007/s00226-0100389-4

Mirek, Z., Piękoś-Mirkowa, H., Zając, A. and Zając, M. (2002). Krytyczna lista roślin naczyniowych Polski [Flowering Plants and Pteridophytes of Poland: a Checklist], Instytut Botaniki PAN im, Władysława Szafera w Krakowie, Cracow, Poland.

Niemczyk, M., Wojda, T., and Kaliszewski, A. (2016). "Biomass productivity of selected poplar (Populus spp.) cultivars in short rotations in northern Poland," New Zealand Journal of Forestry Science 46. DOI: 10.1186/s40490-016-0077-8

Nishimura, K., Ohnishi, M., Masuda, M., Koga, K., and Matsuyama, R. (1983). "Reaction of wood components during maturation," in: Flavour of Distilled Beverages: Origin and Development, J. R. Piggott (ed.), Ellis Horwood Limited, England, pp. 241-255.

Oliver-Villanueva, J. V., Gascón-Garrido, P., and Ibiza-Palacios, M. de S. (2013). "Evaluation of thermally-treated wood of beech (Fagus sylvatica L.) and ash (Fraxinus excelsior L.) against Mediterranean termites (Reticulitermes spp.)," European Journal of Wood and Wood Products 71(3), 391-393. DOI: 10.1007/s00107-013-0687-2

Pandey, K. K., and Pitman, A. J. (2003). "FTIR studies of the changes in wood chemistry following decay by brown-rot and white-rot fungi," International Biodeterioration \& Biodegradation 52(3), 151-160. DOI: 10.1016/S0964-8305(03)00052-0

Poulsen, J. S., Moran, P. N., Shih, C. F., and Byskov, E. (1997). "Kink band initiation and band broadening in clear wood under compressive loading," Mechanics of Materials 25(1), 67-77. DOI: 10.1016/S0167-6636(96)00043-9

Prosiński, S. (1984). Chemia Drewna [Wood chemistry], PWRiL, Warsaw. Poland.

Rowell, R., Sandra, L., McSweeny, J. and Davis, M. (2002). "Modification of wood fiber using steam," in: The $6^{\text {th }}$ Pacific Rim Bio-Based Composites Symposium, Portland, Oregon.

Sandak, A., Sandak, J., and Allegretti, O. (2015). "Quality control of vacuum thermally modified wood with near infrared spectroscopy," Vacuum 114, 44-48. DOI: 10.1016/j.vacuum.2014.12.027

Shchupakivskyy, R., Clauder, L., Linke, N., and Pfriem, A. (2014). “Application of highfrequency densitometry to detect changes in early- and latewood density of oak (Quercus robur L.) due to thermal modification," European Journal of Wood and Wood Products 72(1), 5-10. DOI: 10.1007/s00107-013-0744-X

Sivonen, H., Maunu, S. L., Sundholm, F., and Jämsä, S. (2002). "Magnetic resonance studies of thermally modified wood," Holzforschung 56, 648-654. DOI: 


\subsection{5/HF.2002.098}

Sluiter, A., Hames, B., Ruiz, R., Scarlata, C., Sluitter, J., Templeton, D., and Crocker, D. (2011). Determination of Structural Carbohydrates and Lignin in Biomass, Laboratory Analytical Procedure (LAP) (NREL/TP-510-42618), National Renewable Energy Laboratory (NREL), Golden, CO.

TAPPI T 222 om-15. (2015). “Acid-insoluble lignin in wood and pulp,” TAPPI Press, Atlanta, GA, USA.

Tiemann, H. D. (1944). Wood Technology: Constructions, Properties and Uses, Second Edition, Pitman Publishing Corporation, New York, Chicago, U.S.A.

Wagenführ, R. (2007). Holzatlas [The Atlas of Wood], Fachbuchverlag Leipzig im Carl Hanser Verlag, München, Germany.

Wikberg, H., and Maunu, S. L. (2004). "Characterisation of thermally modified hard- and softwoods by ${ }^{13}$ C CPMAS NMR,” Carbohydrate Polymers 58(4), 461-466. 10.1016/j.carbpol.2004.08.008

Wise, L. E., Murphy, M., and D'Addieco, A. A. (1946). "Chlorite holocellulose, its fractionation and bearing on summative wood analysis and on studies on the hemicelluloses," Paper Trade Journal 122(2), 35-43.

Yildiz, S. and Gümüşkaya, E. (2005). "The effects of thermal modification on crystalline structure of cellulose in soft and hardwood," Building and Environment 42(1), 62-67. DOI: 10.1016/j.buildenv.2005.07.009

Zauer, M., Kretzschmar, J., Großmann, L., Pfriem, A., and Wagenführ, A. (2014). "Analysis of the pore-size distribution and fiber saturation point of native and thermally modified wood using differential scanning calorimetry," Wood Science and Technology 48(1), 177-193. DOI: 10.1007/s00226-013-0597-9

Zawadzki, J. (2009). Wpływ wybranych czynników fizycznych na stopień degradacji celulozy wyodrębnionej z drewna sosny zwyczajnej (Pinus sylvestris L.) [Influence of Selected Physical Factors on the Degree of Degradation of Cellulose Separated from Scots Pine Wood (Pinus sylvestris L.)], Treatises and Monographs series of Publishing WULS- SGGW, Warsaw, Poland.

Zawadzki, J., Antczak, A., Gawron, J., Kłosińska, T., and Radomski, A. (2016). "The influence of heat treatment on the physico-chemical properties of pine wood (Pinus sylvestris L.)." Drewno: Prace Naukowe, Doniesienia, Komunikaty 59(196), 49-57. DOI: 10.12841/wood.1644-3985.135.04

Article submitted: October 14, 2019; Peer review completed: December 30, 2020; Revised version received and accepted: March 11, 2020; Published: April 8, 2020. DOI: $10.15376 /$ biores.15.2.3915-3929 